\title{
Anacardic Acid Isolated From Cashew Nut Shell (Anacardium occidentale) Affects Methane and Other Products in the Rumen Fermentation
}

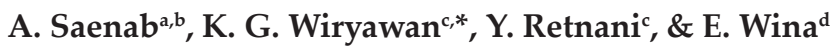 \\ aGraduate School, Bogor Agricultural University \\ bJakarta Assessment Institute for Agricultural Technology, Indonesian Agency for Agricultural Research and \\ Development, Ministry of Agriculture \\ Jalan Ragunan No. Pasar Minggu Jakarta Selatan 12540, Indonesia \\ 'Department of Nutrition and Feed Technology, Faculty of Animal Science, Bogor Agricultural University \\ Jalan Agatis, Kampus IPB Darmaga, Bogor 16680, Indonesia \\ dIndonesian Research Institute for Animal Production \\ Jalan Veteran III, Banjar Waru, Ciawi, Bogor 16720, Indonesia \\ (Received 25-11-2016; Reviewed 10-04-2017; Accepted 22-05-2017)
}

\begin{abstract}
Biofat is a hexane extract containing several bioactive compounds with anacardic acid as the major compound. This study aimed to examine the effect of anacardic acid on rumen fermentation, especially methane and its degradation in the in vitro rumen fermentation. The study was arranged in a completely randomized block design. The treatments were control (substrate or complete feed), biofat (substrate $+0.75 \mathrm{uL} / \mathrm{mL}$ biofat), and anacardic acid (substrate $+0.75 \mathrm{uL} / \mathrm{mL}$ anacardic acid). Measured variables were total gas production, methane, $\mathrm{pH}$, concentration of ammonia $\left(\mathrm{NH}_{3}\right)$, dry matter degrability (DMD), organic matter degrability (OMD), and neutral detergent fiber degrability (NDFD) in the rumen. The chromatogram GC-MS analysis results indicated that the anacardic acid isolation process of the biofat produced nearly pure isolate $(99.44 \%)$, and significantly decreased the production of methane by $51.21 \%$ and $39.62 \%$, respectively. Anacardic acid degradation pattern in the in vitro rumen test showed a shifting of retention factor (Rf) value after anacardic acid being incubated with the degradation of anacardic acid occurred after $24 \mathrm{~h}$ of fermentation. In conclusion, anacardic acid isolated from biofat has a dominant role to reduce the in vitro methane production. Anacardic acid is very potential to be used as a methane reducing agent.
\end{abstract}

Keywords: anacardic, cashew nut sell, methane, rumen fermentation

\section{ABSTRAK}

Biofat adalah produk bioindustri dari kulit cangkang mete yang mengandung beberapa senyawa bioaktif dengan senyawa utama adalah asam anakardat. Penelitian bertujuan untuk menguji efektivitas asam anakardat pada fermentasi rumen, khususnya gas metana dan degradasinya di dalam fermentasi rumen secara in vitro. Penelitian menggunakan rancangan acak kelompok. Perlakuan: kontrol (substrat atau pakan komplit), biofat (substrat + biofat dengan level $0,75 \mu \mathrm{L} / \mathrm{mL}$ ), asam anakardat (substrat + asam anakardat dengan level $0,75 \mu \mathrm{L} / \mathrm{mL}$ ). Peubah yang diukur: produksi gas total, metana, pH, konsentrasi amonia $\left(\mathrm{NH}_{3}\right)$, degradasi bahan kering (DBK), degradasi bahan organik (DBO), dan degradasi serat (DNDF) dalam rumen. Hasil isolasi asam anakardat menghasilkan rendemen sebanyak $8 \mathrm{~g}$ dari $10 \mathrm{~g}$ biofat. Hasil analisis GC-MS menunjukkan bahwa proses isolasi asam anakardat dari biofat menghasilkan senyawa murni $(99,44 \%)$ dan dapat menurunkan produksi metana secara signifikan dibanding kontrol, sebesar 51,21\% oleh biofat dan 39,62\% oleh anakardat. Hasil degradasi asam anakardat dalam fermentasi rumen secara in vitro menunjukkan bahwa perubahan nilai faktor retensi (Rf) setelah diinkubasi. Disimpulkan bahwa asam anakardat yang diisolasi dari biofat memegang peran dominan untuk menurunkan metana pada fermentasi pakan di dalam rumen secara in vitro. Asam anakardat lambat didegradasi oleh bakteri rumen sehingga efektivitasnya dalam menekan gas metana sangat potensial.

Kata kunci: anakardat, kulit cangkang mete, metan, fermentasi rumen

${ }^{*}$ Corresponding author:

E-mail: kgwiryawan61@gmail.com 


\section{INTRODUCTION}

The main product of cashews trees (Anacardium occidentale) are cashew nuts, while the by products are the pseudo-fruits and the cashew nut shells. The processing of cashew nut shell produces bioindustrial product called biofat or better known as CNSL (Cashew Nut Shell Liquid). Biofat contains bioactive substance called anacardic acid. Biofat or CNSL has been widely used for pharmaceutical, cosmetics, adhesives, insecticides, or mosquito repellent (Risfaheri, 2011) and is lately used as animal feed additives for ruminants to suppress methane production in the rumen (Watanabe et al., 2010; Shinkai et al., 2012; Mitsumori et al., 2014). Methane is one of the gases that damage the ozone layer and had 23 times greater effect than carbon dioxide (Vlaming, 2008). By suppressing the production of methane in the rumen, biofat was predicted to be a very useful product to create a friendly environment of farm condition (Mitsumori et al., 2014). Biofat contained 70\% anacardic acid, 20\%$25 \%$ cardol, and the rest was cardanol and methyl cardol (Saenab et al., 2016). Information about the factors in biofat/CNSL that are important in suppressing methane in the rumen is not yet known. Watanabe et al. (2010) assumed that anacardic acid is the main factor that reduce methane production in the in vitro fermentation. However, they did not isolate anacardic acid from CNSL to prove the role of anacardic acid in reducing methane.

The mechanism of decreasing methane production according to Watanabe et al. (2010) was that the phytogenic compounds contained in cashew nut shells (including anacardic acid) selectively inhibited some gram (+) bacteria in the rumen, so that the increased gram (-) bacteria are apparently associated with propionate production. Additionally, the anacardic acid acts as an antibacterial surfactant that can damage the membrane of the gram (+) bacteria. Therefore, this study aimed to examine the effectiveness of anacardic acid addition to substrate in the in vitro rumen fermentation, especially on methane production and to study the anacardic acid degradation in the in vitro rumen fermentation.

\section{MATERIALS AND METHODS}

The research was conducted at the Laboratory of Indonesian Research Institute for Animal Production (IRIAP) Ciawi, Bogor, Indonesia. The GC-MS analysis was conducted in the Jakarta Regional Health Laboratory. The cashew nut shells was obtained from cashew plantation in Pati Regency, Central Java Province, Indonesia.

\section{Preparation of Cashew Nut Shells}

The shells of cashew nuts that had been separated from the nuts were dried in an open sun drying. The dried shells were grinded into smaller particles using a laboratory blender and screened to obtain small size particles ( $2 \mathrm{~mm}$ diameter). Then, the small size cashew nut shells were processed into bioindustrial products namely oil (Biofat).

\section{Preparation of Biofat Product}

The preparation of biofat products used the modified method of Simpen (2008). The method was described in Saenab et al. (2016).

\section{Isolation of Anacardic}

Anacardic acid was isolated using modified method of Gandhi et al. (2012). Briefly, $10 \mathrm{~g}$ of biofat were dissolved in $120 \mathrm{~mL}$ of $5 \%$ methanol solution. While stirring the biofat solution on a stirred hot plate at $50^{\circ} \mathrm{C}$, $10 \mathrm{~g}$ of $\mathrm{Ca}(\mathrm{OH})_{2}$ (Calcium hydroxide) was added slowly with continuous stirring for $3 \mathrm{~h}$ until calcium anacardate was precipitated. Then, the precipitate was filtered and rinsed with $100 \mathrm{~mL}$ of methanol, and the precipitate was poured into $100 \mathrm{~mL}$ of water. Then, $15 \mathrm{~mL}$ of $11 \mathrm{~N}$ hydrochloric acid was added. The samples were then stirred for $1 \mathrm{~h}$ at room temperature. After that, the solution was extracted with hexane $(2 \times 100 \mathrm{~mL})$ and shaken. Hexane layer was separated from the aqueous solution. Furthermore, the hexane extracts were evaporated with a rotary evaporator at $40^{\circ} \mathrm{C}$ until the remained was a thick dark brown fraction called anacardic acid. Characterization of the anacardic acid isolate was conducted qualitatively by TLC and GC-MS.

Aluminium plate used for TLC was a $10 \times 10 \mathrm{~cm}$ Silica gel 60 F254. Eluent1 was a mixture of Diethyl ether (30) + Petroleum ether (70) + formic acid (1) and eluent 2: Diethyl ether (28) + Petroleum ether $(70)+$ formic acid (2). The eluents were put into a TLC tank. The TLC plate was inserted after the tank became saturated. After being finished, the plate was removed from the tank. The plate was set aside to dry and then the plate was sprayed with phosphomolybdicdate acid solution (0.25 $\mathrm{g}$ dissolved in $10 \mathrm{~mL}$ of ethanol). The plate was then placed in the oven at temperature of $105^{\circ} \mathrm{C}$ for $15 \mathrm{~min}$. Blue spot as bioactive compounds will appear with a light yellow background.

Concentration of anacardic acid was analysed using GCMS-QP2010, Shimadzu equipped with column Capiler Type Phase Rtx; $60 \mathrm{~m}$ x $0.25 \mathrm{~mm}$ LD. The carrier gas was helium. Temperature of column, SPL, MS interspace, pyrolysis were 50, 280, 280 and $400^{\circ} \mathrm{C}$, respectively. Inlet Press was $101.0 \mathrm{kPa}$.

\section{Preparation of a Complete Feed for In Vitro Fermentation}

Complete feed for cattle consisted of elephant grass, gliricidia leaves, yellow corn, copra meal, molasses, rice bran, urea, salt $(\mathrm{NaCl})$, limestone $\left(\mathrm{CaCO}_{3}\right)$, and premix. The nutrient compotition of complete feed consisted of $15.63 \% \mathrm{CP}, 3.83 \% \mathrm{CF}, 3785$ Gross Energy (kcal $/ \mathrm{kg})$, 6.85\% Ash, 28.41\% NDF, 15.02\% ADF, 0.69\% Ca, 0.29\% $\mathrm{P}$, and $69.7 \% \mathrm{TDN}$.

This animal feed was used in the in vitro test. The rumen fluid was taken from a fistulated Frisian Holstein crossbreed dairy cow (FH) at the IRIAP Ciawi Bogor. The cow was fed a mixture of napier grass and commercial concentrates. The rumen fluid was collected before the morning feeding and filtered using a nylon cloth, 
then inserted into a thermos. Once collected, the rumen fluid was brought to the laboratory.

\section{Analysis of In Vitro Fermentation}

The rumen buffer liquid composition (in $1000 \mathrm{~mL}$ ) consisted of $241 \mathrm{~mL}$ bicarbonate buffer solution, $121 \mathrm{~mL}$ macro-mineral solution, $61 \mathrm{~mL}$ micro-mineral solution, $0.61 \mathrm{~mL}$ resazurin, $362 \mathrm{~mL}$ distilled water, $23 \mathrm{~mL}$ reducing solution, and $253 \mathrm{~mL}$ rumen fluid (Makkar, 2003).

The samples were incubated following the methods of Theodorou et al. (1994). Substrates of about 750 mg were weighed and put into the incubation bottle. Complete animal feed, biofat, and anacardic acid were added to the tube according to the treatment. In vitro incubation used the mixture of rumen fluid and buffer solution as media. Prior to addition to the sample, the rumen-buffer solutions were flushed with $\mathrm{CO}_{2}$ gas. Then, $75 \mathrm{~mL}$ of rumen-buffer solutions were poured into each incubation bottle and immediately sealed with a rubber cap. Each bottle was incubated in the water bath (Lab master, Anax-Pty, Limited) at $39^{\circ} \mathrm{C}$ and incubated for $48 \mathrm{~h}$. During the incubation period, the shaking process of the bottle was done manually. Gas production was then measured at 3, 6, 9, 12, 24, 30, and $48 \mathrm{~h}$ of incubation. The samples were taken to measure the levels of ammonia and fermented $\mathrm{pH}$ solutions at the $4^{\text {th }}$ hour of the incubation process.

\section{The Experimental Design}

This study was arranged in a completely randomized block design. Three treatments were the control (substrate), biofat (substrate + biofat at the level of 0.75 $\mu \mathrm{L} / \mathrm{mL}$ buffer mixture), anacardic acid (substrate + anacardic acid at the level of $0.75 \mu \mathrm{L} / \mathrm{mL}$ ). These three treatments were prepared in duplicate. The entire in vitro experment were repeated 4 times.

Variables measured were total gas production, methane, $\mathrm{pH}$, concentration of $\mathrm{NH}_{3^{\prime}}$ DMD, OMD, and NDFD in the rumen, as well as anacardic acid degradation.

\section{Determination of Anacardic Acid Degradation}

Approximately $750 \mathrm{mg}$ of elephant grass as substrates and $75 \mathrm{~mL}$ of rumen buffer solution were added into the $100 \mathrm{~mL}$ bottle. Anacardic acid was added to rumen-buffer solution to obtain the concentration of $0.75 \mathrm{uL} / \mathrm{mL}$. The bottles containing the mixture were incubated in a water bath at a temperature of $39^{\circ} \mathrm{C}$ for $48 \mathrm{~h}$. At 3, 6, 12, 24, $48 \mathrm{~h}$ of incubations, $5 \mathrm{~mL}$ were taken from each sample and extracted twice with $5 \mathrm{~mL}$ hexane. Hexane fractions were collected and evaporated in a rotary evaporator, then the residues were redissolved in $2 \mathrm{~mL}$ ethyl acetate to be ready to be used for qualitative analyses by TLC with the same method as anacardic analysis.

\section{RESULTS}

\section{Isolation and Characteristics of Anacardic Acid}

Eight grams of isolated anacardic acid were obtained from the initial weight of $10 \mathrm{~g}$ biofat sample. Qualitatively, the results from the TLC were shown in Figure1 A\&B. The biofat product showed three spots of different compounds each with Rf1 (0.53), Rf2 (0.37), and Rf3 (0.20) (Figure 1A). The isolated anacardic compounds showed the same spot with Rf value similar to the major spot of biofat, but in Figure 1B, the biofat product showed three different compounds with Rf1 (0.68), Rf2 (0.63), and Rf3 (0.47) and the anacardic acid compound produced two spots similar to the major spots in biofat.

The result of GC MS (Figure 2) showed that there was a very high peak at 35.317 minutes as the main peak. The compound had a value of $540 \mathrm{~m} / \mathrm{z}$. The fragmentations were: 355, 327, 302, 267, 230, 207, 175, 161, $147,135,121,108,97,95,81,79,67$, and 55. The analysis showed that the concentration of anacardic acid compounds was $99.44 \%$.

\section{Effects of Anacardic Acid and Biofat on In Vitro Rumen Fermentation}

Figures 3 and 4 showed that the addition of biofat and anacardic acid significantly decreased the production of methane and the total gas compared to the control. Addition of biofat and anacardic acid decreased methane productions by $51.21 \%$ and $39.62 \%$, respectively. Meanwhile, additions of biofat and anacardic acid decreased total gas by 43.33 and $39.34 \%$, respectively.

The additions of biofat and anacardic significantly decreased $(\mathrm{P}<0.01) \mathrm{pH}$ value compared to the control. However, the administration of biofat did not change ammonia level in the rumen. The results of the analysis (Table 1) showed that the dry matter degradation in the rumen significantly decreased $(P<0.01)$ and the degradation of organic matter and NDF also decreased
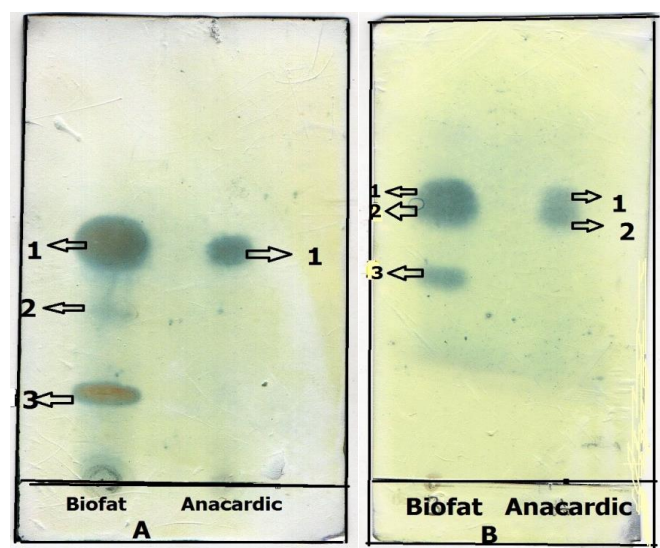

Figure 1. Anacardic and biofat separation on the TLC plate with eluent. Eluent $\mathrm{A}=\mathrm{a}$ mixture of diethyl ether (30) + petroleum ether $(70)+$ formic acid (1); Eluent $\mathrm{B}=\mathrm{a}$ mixture of diethyl ether $(28)+$ petroleum ether $(70)+$ formic acid (2). 


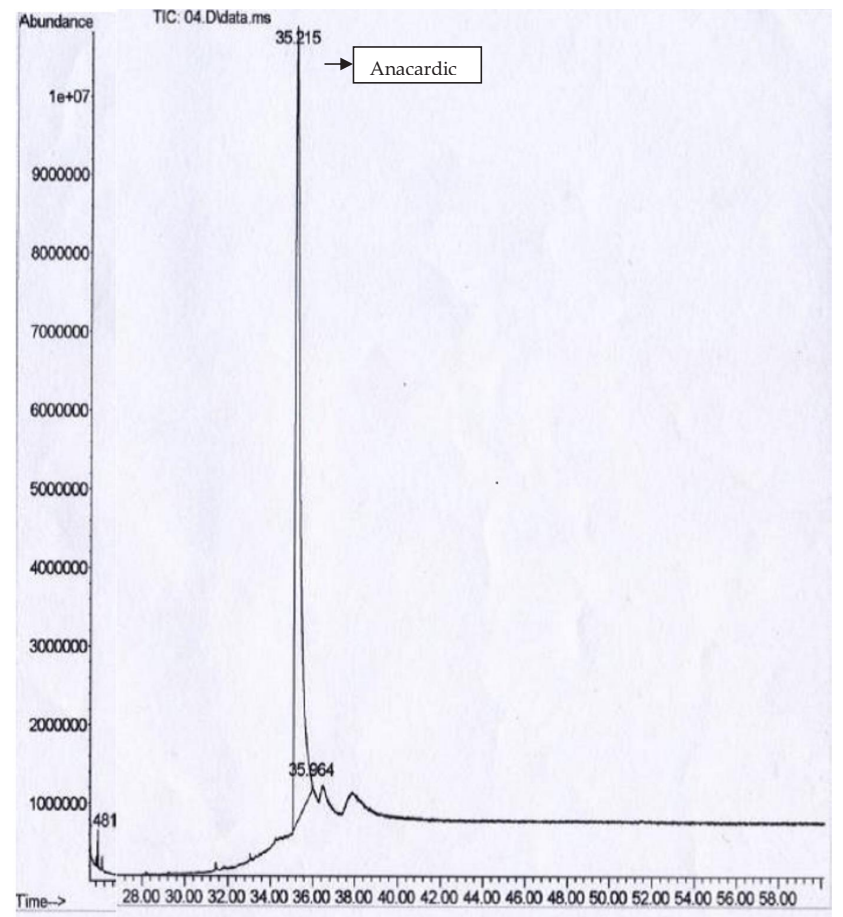

Figure 2. Chromatogram of anacardic acid analysed by GC-MS

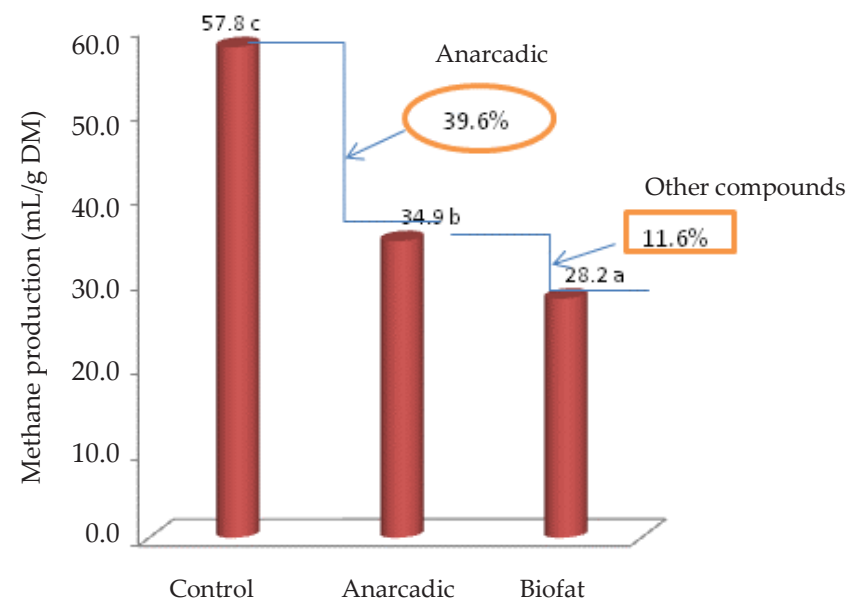

Figure 3. Methane production at 48 hours of incubation in the in vitro rumen fermentation significantly $(\mathrm{P}<0.05)$ on the addition of anacardic acid compared to the control.

\section{Anacardic Acid Degradation During In Vitro Rumen Fermentation}

The anacardic acid degradation in the in vitro rumen fermentation are shown in Figure 5. It was shown in the picture that the $\mathrm{Rf}$ value of anacardic acid before incubation was 0:55. After being incubated for 3-48 h, the spot with different intensities had the Rf value of 0.70 . The strongest intensity of the spot was found at 12 $\mathrm{h}$ of incubation. After 24 hours of incubation, the spot was getting thinner and finally disappeared after $48 \mathrm{~h}$ of incubation.

\section{DISCUSSION}

\section{Isolation of Anacardic Acid from Biofat}

From the isolation process, the yield of anacardic acid amounted to $8 \mathrm{~g}$ from $10 \mathrm{~g}$ biofat or approximately $80 \%$. The result were higher than the yield obtained by Gandhi et al. (2012) who isolated $50 \mathrm{~g}$ of CNSL and generated yield of $26 \mathrm{~g}$, or about $52 \%$. The differences in yield may be due to the different methods used to obtain biofat. The solution used in this experiment was 5\% methanol, while Gandhi et al. (2012) used acetone that has different polarities than $5 \%$ methanol solution.

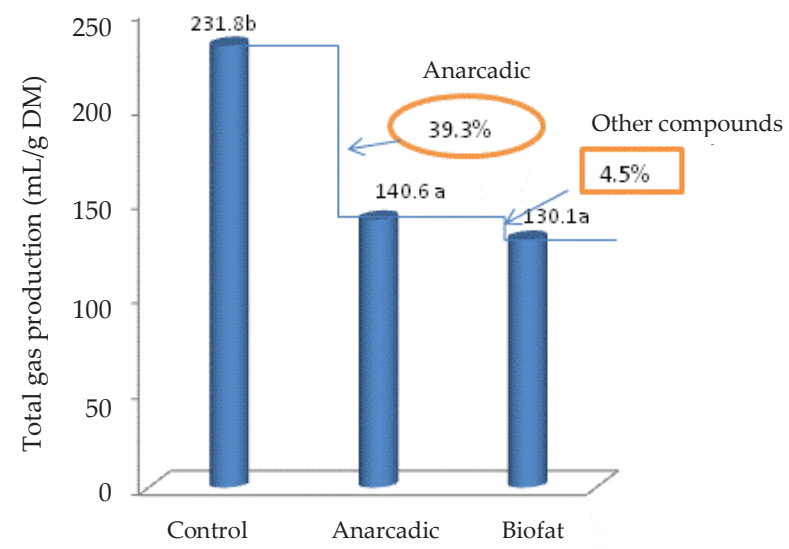

Figure 4. Total gas production at 48 hours of incubation in the in vitro rumen fermentation

Table 1. Ammonia and $\mathrm{pH}$ levels of rumen fluid (after 4-hours incubation), DMD, OMD, and NDFD of feed in control, biofat, and anacardic treatments

\begin{tabular}{lclccc}
\hline Treatments & $\mathrm{NH}_{3}(\mathrm{mM})$ & $\mathrm{pH}$ & $\mathrm{DMD}(\%)$ & OMD (\%) & NDFD (\%) \\
\hline Control & 5.71 & $6.73^{\mathrm{b}}$ & $67.80^{\mathrm{b}}$ & $69.23^{\mathrm{b}}$ & $68.70^{\mathrm{b}}$ \\
Biofat & 5.93 & $6.68^{\mathrm{a}}$ & $58.78^{\mathrm{a}}$ & $60.28^{\mathrm{a}}$ & $51.80^{\mathrm{a}}$ \\
Anacardic & 6.01 & $6.69^{\mathrm{ab}}$ & $63.73^{\mathrm{b}}$ & $66.35^{\mathrm{ab}}$ & $55.12^{\mathrm{a}}$ \\
$\mathrm{SE}$ & 0.51 & 0.01 & 1.24 & 2.15 & 3.42 \\
P Value & 0.871 & 0.044 & 0.006 & 0.064 & 0.028 \\
\hline
\end{tabular}

Note: Means in the same column with different superscripts differ significantly $(\mathrm{P}<0.05)$ 


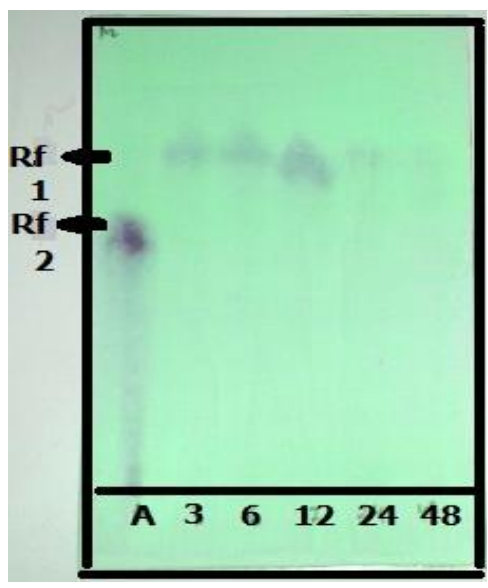

Figure 5. TLC separation of anacardic acid degradation during 48-hours incubation in the in vitro rumen fermentation. Note: A (anacardic acid); 3, 6, 12, 24, 48 (incubation hours).

The isolated compound was analyzed using TLC that showed different results depend on the eluent used. Both eluents were non-polar mixture and the addition of formic acid was more in the second eluent. This caused the second eluent to be slightly more polar. For the first eluent, the flow rate of eluent was faster, so it was unable to separate the spot with the Rf that was almost the same, while the second eluent which was slightly more polar, the eluent flow rate was slower so it could be separated into two spots. Njuku et al. (2014) stated that there were 4 types of anacardic acid compounds with different concentration levels, namely $\mathrm{C}_{15}: 0$ (saturated) with a concentration of $3 \%, \mathrm{C}_{15}: 1$ with a concentration of $34 \%-36 \%, C_{15}: 2$ with a concentration of $21 \%-22 \%$, and $C_{15}: 3$ with a concentration of $40 \%-41 \%$. It is possible that anacardic acids with higher concentrations were appeared on this TLC plate. There was a possibility that saturated anacardic acid did not appear because the concentration was very small.

Chromatogram results of GC-MS analysis (Figure 2) showed that the anacardic acid isolation process of the biofat product succeeded to obtain a pure compound $(99.44 \%)$. Fragments obtained from the GC-MS were equal to those reported by Silva et al. (2008) and Saenab et al. (2016) who showed that the obtained compound was anacardic acid. In addition, the content of anacardic acid compounds in biofat from the cashew nut shells amounted to $78.16 \%$ and with the isolation process, the amount obtained increased to $99.44 \%$. Therefore, the other compounds such as cardol, cardanol, and methyl cardol can be separated from anacardic acid compounds during the isolation process (Gandhi et al., 2012). Furthermore, the results of this isolation were used to test the effectiveness and degrability of anacardic acid in the rumen fluid in vitro.

\section{In Vitro Methane and Gas Production}

The production of methane and total gas (Figures 3 and 4) was lower by the addition of anacardic acid and biofat compared to the control. The inhibition of methane production by anacardic acid was lower than biofat. However, as part of bioactive compounds present inside the biofat, anacardic acid contribution to the total reduction in methane amounted to $77.36 \%$ while the contribution of other compounds amounted to $22.64 \%$. This showed the dominant role of anacardic acid to suppress methane, which was 3 times higher than the role of other bioactive compounds in the biofat. The other compounds besides anacardic acid are cardol, cardanol, dimethyl cardol (Rodrigues et al., 2011; Gandhi et al., 2012; and Njuku et al., 2014), 2-(800Z-eicosenoyl)-6-(80Z-pentadecenyl) salicylic acid, 2-(900Z-hexadecenoyl)-6-(80Z, 110 Z-pentadecadienyl) methyl salicylate, 2-(1000Z, 1300Z-nonadecadienoyl)6-(80Z, 110Z-pentadecadienyl) salicylic acid, 2-(1600Z-penta cosenoyl)-6-(80Z-pentadecenyl) salicylic acid, and 2-(900Z-octadecenoyl)-6-(80Z, 110 Z-pentadecadienyl) methyl salicylate (Suo et al., 2012).

In the previous study, Watanabe et al. (2010) reported that anacardic acid reduced methane production. However, they did not conduct the anacardic acid isolation process. They only changed the composition of CNSL (biofat) by heating process at high temperature so that the anacardic acid turned into cardanol. They reported that the heated CNSL which contained cardanol $(73.9 \%)$ had no effect in lowering methane, whereas the unheated CNSL which contained anacardic acid (62.3\%) can reduce methane production.

Biofat can decrease methane because biofat contains several bioactive compounds, one of which is the anacardic acid. The content of anacardic acid in biofat is very high and as the major bioactive compound, it gives a dominant influence of lowering methane. This can be seen from the results of the study (Figure 3) where the acid decreased methane $(39.6 \%)$. These anacardic acids are antibacterial and can suppress methanogen activity thereby decreasing methane.

The inhibition of the total gas formation by anacardic acid was amounted to $39.34 \%$ and by biofat was amounted to $43.33 \%$. However, inhibition by other compounds in biofat was only $4.52 \%$. This research showed the dominant role of anacardic acid to suppress total gas was 8 times higher than other bioactive compounds. This result showed that anacardic acid did not only inhibit the formation of methane but also inhibited the formation of other gases that were the results of the activities of other microbes in the rumen. Inhibitions of the activities of rumen microbe were indicated by the decreased degrabilities of dry matter, organic matter, and neutral detergent fiber of the feed in this experiment. It was confirmed by the study of Watanabe et al. (2010) who reported that the population of some bacteria in the rumen were reduced due to the addition of unheated CNSL, namely Prevotella ruminocola, Prevotellabryantii, Treponemabryantii, Ruminococcus flavifaciens, and Fibrobacter succinogenes. These bacteria have the ability to break down fiber and capable of forming propionate and succinate.

Anacardic acid showed negative influences on the activity and the population of methanogenic microbes and the other bacteria. This may be caused by the ana- 
cardic acid structures which have phenolic cluster and unsaturated fatty acids. It was reported that phenolic had negative effect on rumen bacteria (Jayanegara et al., 2011) and unsaturated fatty acids (PUFAs) were olso toxic to rumen bacteria (Kim et al., 2009).

The mechanism for reducing methane may also be similar to the mechanism by other phenolic compounds which inhibit the methanogenic microbes and fiber degrading bacteria that eventually decrease the degrability. In contrast to tannin which inhibited protein degrading bacteria, the anacardic acids in this experiment did not inhibit protein degrading bacteria and also did not inhibit the formation of $\mathrm{NH}_{3}$. Besides, anacardic acid is a powerful amphifilic lipid phenolic that can interact with the cell's wall or membrane structure and the hydrophobic domain of the protein (Kim et al., 2009 and Watanabe et al., 2010).

\section{Anacardic Acid Degradation in the In vitro Rumen Fermentation}

The anacardic acid degradation in the rumen was analyzed by using TLC (Figure 4) showing a shift of Rf value of anacardic acid compounds after being incubated in the rumen. It was assumed that before incubation, the thick spot ( Rf 0.55) were the unsaturated anacardic acid compounds. It was reported by Tyman et al. (1996) that the fatty acids of anacardic acid compound in the saturated form have higher $\mathrm{Rf}$ value than those in the unsaturated form. This result implied that during the incubation in the rumen, there was a change in the chemical structure of anacardic acid. After 12 hours of incubation, a thicker spot was visible, showing that the entire unsaturated anacardic acid became all saturated. This process of structure change from unsaturated to become saturated form is called hydrogenation process which is carried out by the rumen bacteria (Kim et al., 2009 and Lejonklev et al., 2013). The hydrogenation process is bacteria's strategy to prevent itself because unsaturated fatty acid is toxic to rumen bacteria (Kim et al., 2009). After $24-48 \mathrm{~h}$, the spot was disappeared. This result was probably due to the degradation of anacardic acid into simple phenol and free fatty acids. A complete disappearance of anacardic acid in the in vitro rumen took rather long time ( 24 hour of incubation) suggesting that anacardic acid was not easily degraded in the rumen. Furthermore, phenolic acids may be degraded by enzymes into simpler compounds (Cao et al., 2015). Some fatty acids are absorbed by the rumen and some are used by the microbes itself (Jenkins et al., 2008).

\section{CONCLUSION}

Anacardic acid isolated from biofat has a dominant role in the biofat product to decrease methane production in the rumen fermentation. As it is slowly degraded by rumen bacteria, anacardic acid is very potential as a methane reducing agent. Considering its effect to reduce degradability in the rumen, the level of anacardic acid to be used as a methane reducing agent should be further evaluated in vivo.

\section{ACKNOWLEDGEMENT}

The author would like to thank Indonesian Agency For Agricultural Research and Development, Ministry of Agriculture for financing this research through the research grant No. 242/KPts/KU.010/1.1/07/2015dated 9 July 2015.

\section{REFERENCES}

Cao, B. B., R. Wang, H. J. Yang, \& L. S. Jiang. 2015. In situ ruminal degradation of phenolic acid, cellulose and hemicellulose in crop brans and husks differing in ferulic and pcoumaric acid patterns. J. Agric. Sci. 153:1312-1320. https:// doi.org/10.1017/S0021859615000489

Gandhi, T., M. Patel, \& B. K. Dholakiya. 2012. Studies on effect of various solvents on extraction of cashew nut shell liquid (CNSL) and isolation of major phenolic constituents from extracted CNSL J. Nat. Prod. Plant Resour. 2 :135-142.

Jayanegara A, E. Wina, C. R. Soliva, S. Marquardt, M. Kreuzer, \& F. Leiber. 2011. Dependence of forage quality and metanogenic potential of tropical plants on their phenolic fractions as determined by principal component analysis. Anim. Feed Sci. Technol. 163: 231-243. https://doi. org/10.1016/j.anifeedsci.2010.11.009

Jenkins, T. C., R. J. Wallace, P. J. Moate, \& E. E. Mosley. 2008. Board-invited review: Recent advances in biohydrogenation of unsaturated fatty acids within the rumen microbial ecosystem. J. Anim. Sci. 86:397-412. https://doi.org/10.2527/ jas.2007-0588

Kim, U. E., A. H. Sharon, R. F. L. Michael, \& D. N. Scollan. 2009. Dietary transformation of lipid in the rumen microbial ecosystem. Asian-Australas. J. Anim. Sci. 22:13411350. https://doi.org/10.5713/ajas.2009.r.11

Lejonklev, J., A. C. Storm, M. K. Larsen, G. Mortensen, \& M. R. Weisbjerg. 2013. Differences in rate of ruminal hydrogenation of $\mathrm{C} 18$ fatty acids inclover and ryegrass. J. Anim Sci. 7:1607-1613

Njuku, F. W., P. M. Mwangi, \& G T. Thiong'o. 2014. Evaluation of cardanol acetate as a reactive diluent for alkyd coatings. Int. J. Adv. Res. 2: 928-941

Makkar, H. P. S. 2003. Quantification of Tannin in Tree an Shrub Foliage. A Laboratory Manual. Kluwer Academic Publisher, Dordrecht, The Netherlands, 102 pp. https://doi. org/10.1007/978-94-017-0273-7

Mitsumori, M., O. Enishi, T. Shinkai, K. Higuchi, A. Takenaka, K. Nagashima, M. Mochizuki, \& Y. Kobayashi. 2014. Effect of cashew nut shell liquid on metabolic hydrogen flow on bovine rumen fermentation. J. Anim. Sci. 85:27-32. doi: 10.1111/asj.12133. https://doi.org/10.1111/asj.12133

Risfaheri, T., T. Irawadi, M. A. Nur, \& I. Sailah. 2011. Pemisahan kardanol dari minyak cangkang biji mete dengan metode mestilasi vakum. Balai Besar Penelitian dan Pengembangan Pascapanen Pertanian. J. Pascapanen 1: $1-11$.

Rodrigues, F. H. A., F. C. F. França, J. R. R. Souza, N. M. P. S. Ricardo, \& J. P. A. Feitosa. 2011. Comparison between physico-chemical properties of the technical Cashew Nut Shell Liquid (CNSL) and those natural extracted from solvent and pressing. Polímeros 21: 156-160. https://doi. org/10.1590/S0104-14282011005000028

Saenab, A., K. G. Wiryawan, Y. Retnani, \& E. Wina. 2016. Phisical and chemial characteristics of bioIndustry products of cashew nuts shell (Anacardium occidentale). J. Littri. 22:81-90. https://doi.org/10.21082/littri.v22n2.2016.81-90

Silva, M. S., S. G. D. E. Lima, E. H. Oliveira, J. A. D. Lopes, M. H. Chaves, F. A. M. Reis, \& A. M. G. L. Cito. 2008. Anacardic acid derivatives from brazilian propolis and 
their antibacterial activity.Ecl. Quím São Paulo. 33: 53-58

Shinkai, T., O. Enishi, M. Mitsumori, K. Higuchi, A.Takenaka, K. Nagashima, M. Mochizuki, \& Y. Kobayashi. 2012. Mitigation of methane production from cattle by feeding cashew nut shell liquid. J. Dairy Sci. 95:5308-5316. https:// doi.org/10.3168/jds.2012-5554

Simpen, I. N. 2009. Isolasi cashew nut shell liquid dari cangkangl biji jambu mete (Anacardium occidentale L) dan kajian beberapa sifat fisiko-kimianya. Jurnal Kimia 2: 71-76.

Suo, M., I. Hasegawa, I. Yoshihiro, S. Yasoku, B. Changxiao, K. Hikaru, T. Fumihide, \& O. Tomihisa. 2012. Phenolic lipid ingredients from cashew nuts. J. Nat Med 66:133-139. https://doi.org/10.1007/s11418-011-0564-4

Theodorou, M. K., B. A. Williams, M. S. Dhanoa, A. B. Mc Allan, \& J. France. 1994. A simple gas production method using a pressure transducer to determine the fermentation kinetics of ruminant feeds. Anim. Feed Sci. Technol. 48:185-197. https://doi.org/10.1016/0377-8401(94)90171-6
Tyman, J. H. P. D., M. A. Wilczynski, \& A. Kashani. 1996. Compositional studies on technical cashew nutshell liquid (CNSL) by chromatography and mass spectroscopy. In: Phenols / Thin Layer (Planar) Chromatography. J Am Oil Chem Soc. 55: 663-668. https://doi.org/10.1007/BF02682455

Vlaming, J.B. 2008. Quantifying Variation in Estimated Methane Emission from Ruminants Using the SF6 Tracer Fechnique. A Thesis of Doctor of Phylosophy in Animal Science. Massey University, Palmerston North, New Zealand.

Watanabe, Y., R. Suzuki, S. Koike, K. Nagashima, M. Mochizuki, R. J. Forster, \& Y. Kobayashi. 2010. In vitro evaluation of cashew nut shell liquid as a methaneinhibiting and propionate-enhancing agent for ruminants. J. Dairy Sci. 93:5258-5267. https://doi.org/10.3168/ jds.2009-2754 